\title{
Evaluation of the VIG Insurance Group's Insurance Portfolio in the Czech Republic
}

\author{
Lenka Přečková \\ Silesian University in Opava \\ School of Business Administration in Karviná, Department of Finance and Accounting \\ Univerzitní nám. 1934/3, 73340 Karviná, Czech Republic \\ E-mail: preckova@opf.slu.cz
}

\begin{abstract}
This article aims to determine whether the developments in the insurance business production correspond with the development of the expense-to-revenue ratio of an insurance portfolio. The subject of the research is insurance companies belonging to the VIG insurance group in the Czech Republic. Its commercial production, i. e. insurance business, will be evaluated. The evaluation will be performed by analysis and comparison of financial ratio indicators for the period 2005-2013. The insurance business will be first examined by market positions through market share, increase in gross written premiums and product diversification. Subsequently, insurance business will be evaluated by cost ratio indicators, namely by expense ratio and loss ratio. The expense-to-revenue ratio and product diversification will be assessed in the non-life segment. Finally, a comparison will reveal whether the development of market position corresponds with the development of operating costs and costs expended on insurance benefits.
\end{abstract}

Keywords: relative market share, the cost of taking out insurance, the cost of insurance management, insurance benefits costs

JEL codes: G22

\section{Introduction}

This article reflects on the current situation of how to assess insurers in the Czech insurance market. In various statistics and annual reports the insurance market is primarily assessed from the perspective of commercial production, i. e. market position and growth in premiums written. This is very aptly described by Lhotská (2012, p. 23): "We are witnessing a competition aimed at maximizing market share in the volume of premiums written." Lhotská (2012, p. 23) notes that the insurance market is not so much threatened by irregularities in the distribution, climate changes and the very current issue of new legal regulation of the insurance market. The main threat to the insurance market is short-sightedness of insurance companies pursuing a "swift victory". Insurance companies, instead of profitability and benefits from insurance contracts, pursue primarily volume of new production.

Lhotská (2013, p. 28) points out that insurance companies should concentrate on the quality of their insurance portfolios and thus seek to improve the outcome of their own insurance business. Insurance companies should achieve an adequate quality of 
their insurance portfolio and a suitable product structure. The quality of an insurance portfolio, i. e. plurality of contracts of all products, can be defined by various parameters. It is suitable to evaluate claims ratio and cost management portfolio. Lhotská (2015, p. 13) emphasizes the charm of the market share and the fact that every insurance company is pleased "when its insurance company has a bigger pie chart than its competitors." According to Lhotská, this aspect is overrated and steps to ensure greater market share may even be counterproductive, as evidenced by the history of Czech liability insurance. It should be noted that the market share must not be superordinate to the priority of insurance companies which is their profit. Profit is related not only to the size of the portfolio, but also to its quality. Řezáč (2009, pp. 158-162) presents results of his research conducted into the use of commercial insurance market strategies in 2004. According to this research, $77 \%$ of insurance companies seek to grow and $46 \%$ would like to increase or maintain their market position, which confirms Lhotská's approach to evaluating insurance market (2012, 2013 and 2015). Speaking of Řezáč's research (2009), it is also interesting to mention his stating that the cost strategy is implemented by $15 \%$ of insurance companies. Most commercial insurers assess the state of the insurance market in the Czech Republic as stable and they do not anticipate disproportionate cost increases.

The object of my research is the Vienna Insurance Group (hereinafter referred to as VIG), which is due to its market share among the most important insurers in the Czech Republic. This group is formed by Kooperativa pojistovna, a. s., Vienna Insurance Group (KOOP), Česká podnikatelská pojištovna, a. s., Vienna Insurance Group (ČPP) and Pojištovna České spořitelny, a.s., Vienna Insurance Group (PČS). To complete the picture, it should be noted that the second major insurance group in the Czech Republic is PPF - Generali, which was founded in 2008. The market share of this insurance group was in the period 2008-2013 about 2\% higher than the VIG's (annual reports of Czech Insurance Association).

KOOP was founded in 1991 as the first commercial insurance company in former Czechoslovakia and since its inception it has been part of the VIG. In early 2004 a strategic partnership agreement was concluded between KOOP and Česká spořitelna, a. s. (hereinafter referred to as Čs). (www.koop.cz, 2015)

The strategic partnership of KOOP and Čs is connected with the historical development, which started with the creation and development of Čs-Živnostenská pojištovna, a. S., founded in 1992 by ČS's Czech private capital. In 2000, ČsŽivnostenská pojištóvna, a.s., welcomed a new shareholder, the largest Austrian life insurer Sparkassen Versicherung, a member of the financial group Erste Bank. Since 2001, the insurer began using the new name Pojištovna České spořitelny (PČS). This was soon followed by development of bancassurance through the sale of PČs's insurance products offered in the Čs's branch network. Because Čs and Erste Bank specialized in life insurance and bancassurance, in 2003, stockholders sold the PČS's 
non-life insurance segment to KOOP. Since 2004, the PČS has specialized only in selling life insurance through ČS's network and selected external networks. (www.pojistovnacs.cz, 2015)

KOOP is owned by three companies. These are: VIENNA INSURANCE GROUP AG Wiener Versicherung Gruppe (96.32\%), VLTAVA majetkoprávní a podílová spol. s r. o. $(2.07 \%)$ and Svaz českých a moravských výrobních družstev, Praha (1.61 \%). (www.koop.cz, 2015)

ČPP is a universal insurance company operating in the Czech insurance market since 1995. The ČPP has historically had a strong position in car insurance, especially in compulsory insurance. With more than a million insured vehicles in the Czech Republic it is the third largest provider of this type of insurance in the Czech market. Since 2005, the ČPP has been part of the VIG. The insurance company is owned by a single company, Kooperativa pojištovna, a.s., Vienna Insurance Group. (www. cpp.cz, 2015)

The abovementioned evolution is essential for characterizing PČs. In 2004, PČs began to specialize in selling life insurance through the ČS's network and selected external networks (see information on KOOP). Since 2001, the insurance company has operated under the name PČS developing bancassurance. In 2008, the insurance company became part of the insurance group VIG. The insurance company focuses on premium life insurance products and it is one of the largest insurers in bancassurance in the Czech market. PČs is owned by three companies. These are VIENNA INSURANCE GROUP AG Wiener Versicherung Gruppe (90\%), Kooperativa pojistovna, a. s., Vienna Insurance Group ( $5 \%$ ) and Česká spořitelna, a. s. (5\%). (KOOP's annual report 2012)

\section{Methodology}

This article aims to determine whether the development in the insurance business production corresponds with the development of the expense-to-revenue ratio of insurance portfolios. I evaluate the commercial production, i. e. the insurance business, by gross premiums and the cost of insurance business within the insurance group VIG ČR in general, and according to the insurance companies belonging to the group. To achieve the goal it is necessary to calculate and then analyze and compare selected financial ratio indicators in the period 2005-2013; subsequently, it is determined whether the development of market position corresponds with the development of operating costs and insurance benefits costs. In this article, the indicators are always meant for individual insurers and at the same time for the entire VIG since 2005. Since 2008, all evaluated insurers have been part of the group. Therefore, this fact was taken into account as well. Average values for comparison of the VIG are calculated for the period 2005-2013. 
Ratio indicators used in the insurance industry are based on general ratio indicators used in corporate financial analyses. However, in the world of insurance they must be adapted because of the distinctions. (Vávrová, 2014). According to Vávrová (2014), the aim of commercial insurers' activities is not only the insurance or reinsurance business but also investing funds that are temporarily available. Commercial insurers must set the price of insurance protection without their exactly knowing the costs associated with the services provided. The insurance company must be able to manage a portfolio of insurance contracts, i. e. the insurance portfolio and investment portfolio.

The first part of this research focuses on the analysis of gross written premiums (hereinafter referred to as GWP) and indicators that are used to calculate the GWP. For this reason, I had to calculate market share by GWP in individual insurance companies and within the VIG for the abovementioned period. I then calculated the relative market share (RMS). This indicator is used by the rating agency Moody's (www.moodys.com) - the ratio of premiums written and the average of written premiums in the selected country:

$$
R M S=\frac{G W P}{\text { Average } G W P}
$$

Subsequently, I also analyzed the annual increase in GWP, as this indicator should demonstrate growth; the recommended value according to Korobczuk (2007) is in the range between $-10 \%$ and $+30 \%$. According to Vávrová (2004), new insurance companies make effort to reach a higher growth rate in the early years, and this indicator must be considered marginal in new insurance markets.

Another part of my research focuses on the non-life insurance segment. The reason for this concentration is primarily reporting of statistics and the type of the selected indicator. I will analyze the distribution of insurance products. Product diversification is also assessed by the rating agency Moody's (www.moodys.com) and insurance products are evaluated by whether or not they achieve at least $10 \%$ of premiums written.

Furthermore, I also calculated and assessed the cost items of non-life insurance. I calculated the ratio indicator "expense ratio" (ER), which is very often used in evaluating costs of insurance activities (Pulchart, 2002; Korobczuk, 2007; Gestel et al., 2007; Vávrová, 2014). It is the proportion of operating costs and premiums written. For the calculation I took into account gross operating expenses (GOE) and gross premiums written (GWP). This indicator should reach an amount lower than 30\% (Vávrová, 2004; Korobczuk, 2007). The formula for the calculation is:

$$
E R=\frac{G O E}{G W P}
$$


The last indicator is the loss ratio (LR) (Pulchart, 2002). This is the share of insurance benefits costs (GBC) and premiums written. For the calculations I worked with gross values. The lowest values are most favorable for insurance companies. The formula for the calculation is:

$$
L R=\frac{G B C}{G W P}
$$

\section{Data}

Data used for the calculation of financial ratios were taken from the following Internet sources: GWP is drawn from the financial section of annual reports of individual insurers, precisely from the Special section to the technical account of non-life insurance. The total GWP and number of insurance companies in the Czech Republic was found in ČNB statistics, i. e. Basic indicators of the sectors of the financial market and the Report on supervision performance. For the specification of insurance products (hereinafter referred to as IP) and values of GWP, I used the statistics created by Czech Insurance Association (hereinafter referred to as ČAP). The information was found in the document named Individual results of ČAP's members. ČAP's statistics are selected because of their unified classification by products and reporting GWP for these products. Gross operating expenses and gross claims incurred were searched for in the annual reports of insurance companies, also this time in the Special section to the technical account of non-life insurance.

Liability insurance is offered merely by KOOP; it is included in non-life insurance.

\section{Evaluation of VIG's business activities}

\subsection{Market Share and Relative Market Share}

KOOP is the second largest insurer in the Czech Republic by market share in GWP within the entire period from 2005 to 2013.

Figure 1 shows that KOOP's market share decreased by $2.66 \%$ over the period. ČPP and PČS have both reached a market share of around $5 \%$ in recent years. Their share in the period 2005-2013 grew. If we compare both insurance companies, it is clear that the insurer PČs increased its market share almost 3.5 times, and insurer ČPP almost 1.5 times. In the years 2011-2013, both insurers shared the 6th and 7th rank in the Czech insurance market. For comparison of the development it is important to note that in 2005 PČS ranked tenth in the Czech insurance market and ČPP ranked seventh. The other market share shown in Figure 1 is the one of the insurance group VIG. In the monitored period, this share rose and in 2013 reached almost $32 \%$. 
Figure 1 Development of VIG's market share in the Czech Republic by GWP

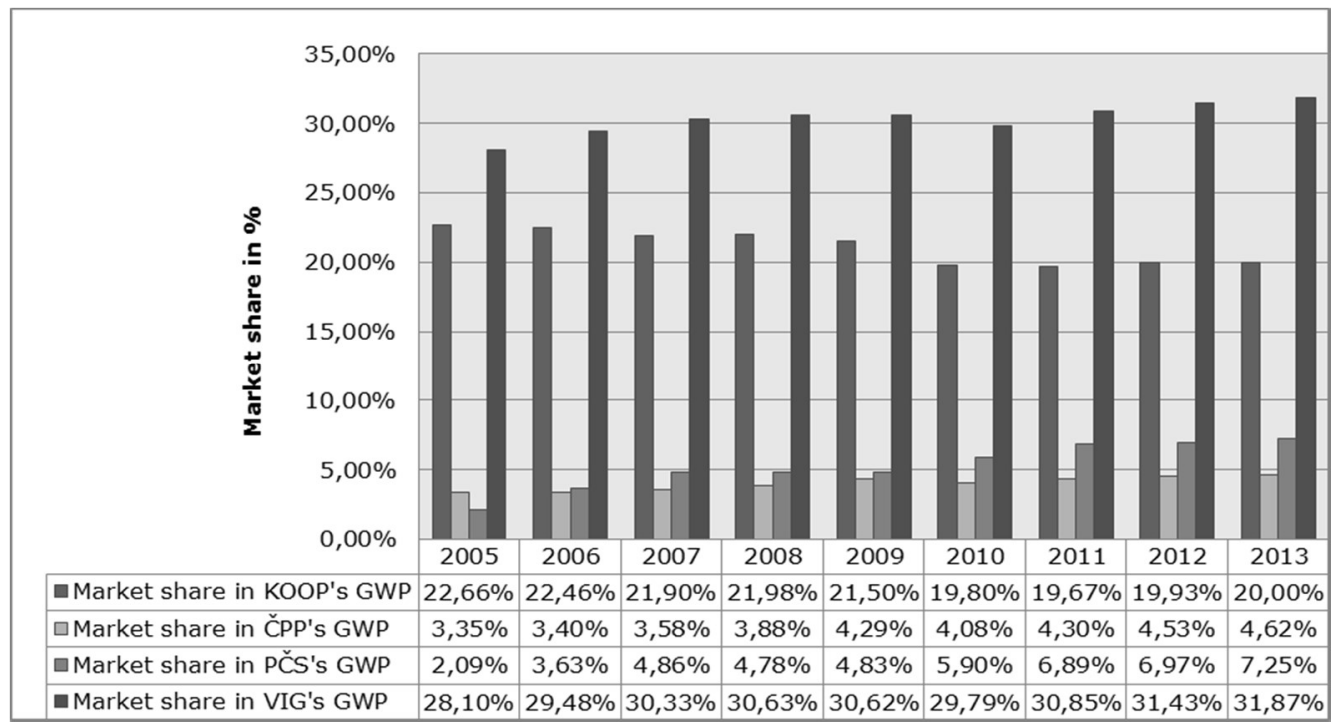

Source: Author's own work based on ČNB's statistics and insurers' annual reports

Another important indicator for the assessment of the position in the insurance market is the relative market share (RMS). The development of the relative share in the Czech insurance market is shown in Figure 2.

Figure 2 Development of VIG's relative market share in the Czech Republic

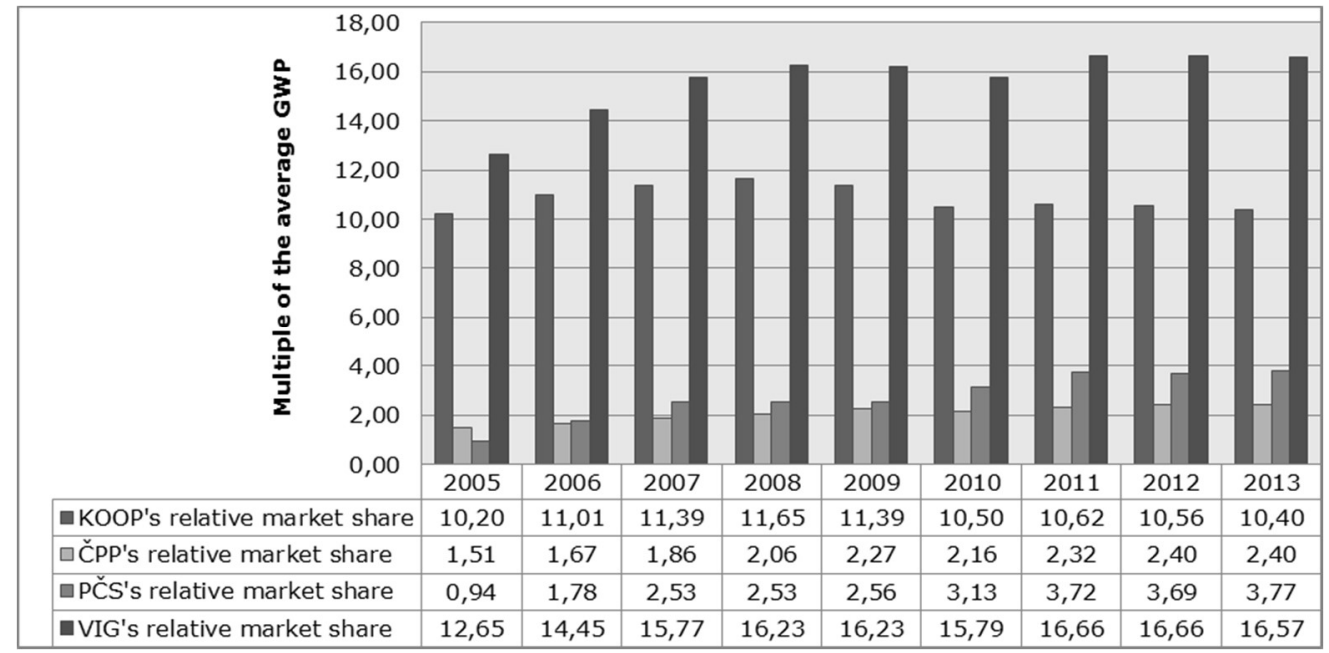

Source: Author's own work based on ČNB's statistics and insurers' annual reports

Moody's rating assesses multiples of the average GWP and then assigns a rating level accordingly. For evaluating a relative share which is at least three times greater, an Aaa rating is assigned (high level), which corresponds with KOOP's and VIG's results. In the period 2010-2013 Aaa rating was reached by PČs as well. The insurance 
company ČPP reached, in the whole period, an Aa rating (good), because it stayed in the range between 1.5 times and 3 times the GWP.

The graphic representation shows a noticeable growth of the relative share of all insurance companies. The lowest increase is manifested by the KOOP insurance company. The highest growth (four times) was reached by PČS. ČPP's indicator increased by almost $60 \%$. VIG has increased its relative share since 2008 by at least $0.02 \%$.

\subsection{Increase in Gross Written Premiums}

Increase in gross written premiums (or growth rate) is the most commonly monitored indicator in the insurance market and it is graphically illustrated in Figure 3. Growth rates of insurance companies in the period were in positive territory. Only KOOP reached negative values in the period between 2009/2010 and 2010/2011. In the other years, KOOP's values were positive and the average rate was $2.13 \%$. ČPP achieved the highest values (14\%) in the years $2006 / 2007$ to $2009 / 2010$ and the average increase was $8.04 \%$. PČs shows the greatest fluctuation in the monitored period; the average increase amounts to $23.59 \%$. VIG has reached $3.11 \%$ (since 2008) of average increase in GWP.

Figure 3 Development of GWP increase within VIG (Czech Republic)

\begin{tabular}{|c|c|c|c|c|c|c|c|c|c|}
\hline \multirow{8}{*}{ 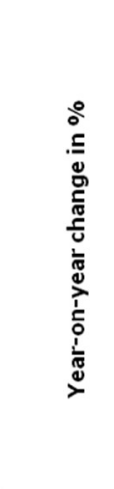 } & \multicolumn{9}{|l|}{$75,00 \%$} \\
\hline & \multicolumn{9}{|l|}{$65,00 \%$} \\
\hline & $55,00 \%$ & & & & & & & & \\
\hline & \multicolumn{9}{|l|}{$35,00 \%$} \\
\hline & \multicolumn{9}{|l|}{$25,00 \%$} \\
\hline & \multicolumn{9}{|l|}{$15,00 \%$} \\
\hline & $5,00 \%$ & 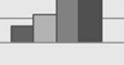 & & & & & & & \\
\hline & $-5,00 \%$ & $\begin{array}{c}2005 / 20 \\
06\end{array}$ & $\begin{array}{c}2006 / 20 \\
07\end{array}$ & $\begin{array}{c}2007 / 20 \\
08\end{array}$ & $\begin{array}{c}2008 / 20 \\
09\end{array}$ & $\begin{array}{c}2009 / 20 \\
10\end{array}$ & $\begin{array}{c}2010 / 20 \\
11\end{array}$ & $\begin{array}{c}2011 / 20 \\
12\end{array}$ & $\begin{array}{c}2012 / 20 \\
13\end{array}$ \\
\hline \multicolumn{2}{|c|}{$\square$ KOOP's growth rate } & $3,39 \%$ & $6,12 \%$ & $5,58 \%$ & $0,87 \%$ & $-0,33 \%$ & $-1,27 \%$ & $0,37 \%$ & $2,30 \%$ \\
\hline \multicolumn{2}{|c|}{$\square$ ČPP's growth rate } & $5,78 \%$ & $14,46 \%$ & $14,17 \%$ & $14,03 \%$ & $3,00 \%$ & $4,66 \%$ & $4,37 \%$ & $3,84 \%$ \\
\hline \multicolumn{2}{|c|}{$\square$ PČS's growth rate } & $80,64 \%$ & $45,76 \%$ & $3,51 \%$ & $4,23 \%$ & $32,17 \%$ & $16,05 \%$ & $0,21 \%$ & $6,11 \%$ \\
\hline \multicolumn{2}{|c|}{ VIG's growth rate } & $9,43 \%$ & $11,96 \%$ & $6,26 \%$ & $3,06 \%$ & $5,26 \%$ & $2,97 \%$ & $0,89 \%$ & $3,36 \%$ \\
\hline
\end{tabular}

Source: Author's own work based on insurers' annual reports

Recommended values of increase in GWP are between $-10 \%$ and $+30 \%$, which all insurers met, except PČs. High growth in GWP in years 2005/2006/2007 was probably caused by strategic changes in 2001 and 2004. Thanks to these changes, the PČS can be considered a "new" insurance company specializing in life insurance through bancassurance. 


\subsection{Product Diversification}

For the correct assessment of insurers' insurance portfolios it is important to learn more about the structure of IP. Firstly, it is necessary to divide GWP into life and nonlife insurance. This is reflected by Table 1 below showing results of KOOP, ČPP and PČs within the monitored time period.

Table 1 Ratio of non-life and life insurance within GWP within VIG (Czech Republic)

\begin{tabular}{lccccccccc} 
Indicator & 2005 & 2006 & 2007 & 2008 & 2009 & 2010 & 2011 & 2012 & 2013 \\
\hline $\begin{array}{l}\text { Ratio of non-life } \\
\text { GWP KOOP, \% }\end{array}$ & 77.24 & 77.13 & 76.29 & 75.88 & 75.17 & 72.95 & 71.28 & 70.24 & 68.44 \\
\hline $\begin{array}{l}\text { Ratio of life GWP } \\
\text { KOOP, \% }\end{array}$ & 22.76 & 22.87 & 23.71 & 24.12 & 24.83 & 27.05 & 28.72 & 29.76 & 31.56 \\
\hline $\begin{array}{l}\text { Ratio of non-life } \\
\text { GWP ČPP, \% }\end{array}$ & 79.55 & 78.59 & 74.42 & 74.20 & 72.87 & 70.93 & 70.16 & 69.76 & 69.18 \\
\hline $\begin{array}{l}\text { Ratio of life GWP } \\
\text { CPP, \% }\end{array}$ & 20.45 & 21.41 & 25.58 & 25.80 & 27.13 & 29.07 & 29.84 & 30.24 & 30.82 \\
\hline $\begin{array}{l}\text { Ratio of non-life } \\
\text { GWP PČS, \% }\end{array}$ & 0.43 & 0.54 & 0.82 & 1.30 & 1.53 & 7.42 & 7.37 & 7.52 & 6.70 \\
\hline $\begin{array}{l}\text { Ratio of life GWP } \\
\text { PČS, \% }\end{array}$ & 99.57 & 99.46 & 99.18 & 98.70 & 98.47 & 92.58 & 92.63 & 92.48 & 93.30 \\
\hline
\end{tabular}

Source: Author's own work based on insurers' annual reports

Having compared the values in Table 1 in the monitored period, it can be summarized that the market share of life insurance GWP increased and in 2013 exceeded the value of $30 \%$ for KOOP and ČPP. In 2013, the insurance group VIG reached ratio of life insurance of around 55\% GWP. This would not have been possible without PČS, which focuses primarily on life insurance.

Figure 4 Development of VIG's ratio of non-life and life insurance GWP (Czech Republic)

\begin{tabular}{|c|c|c|c|c|c|c|c|c|c|c|}
\hline \multirow{9}{*}{ 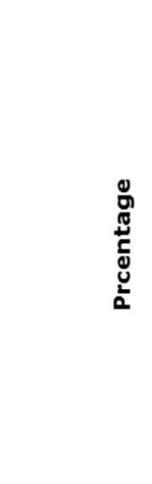 } & \multicolumn{10}{|l|}{$80,00 \%$} \\
\hline & \multicolumn{10}{|l|}{$70,00 \%$} \\
\hline & \multicolumn{10}{|l|}{$60,00 \%$} \\
\hline & \multicolumn{10}{|l|}{$50,00 \%$} \\
\hline & \multicolumn{10}{|l|}{$40,00 \%$} \\
\hline & \multicolumn{10}{|l|}{$30,00 \%$} \\
\hline & \multicolumn{10}{|l|}{$20,00 \%$} \\
\hline & \multicolumn{10}{|l|}{$10,00 \%$} \\
\hline & $0,00 \%$ & 2005 & 2006 & 2007 & 2008 & 2009 & 2010 & 2011 & 2012 & 2013 \\
\hline \multicolumn{2}{|c|}{ EIG's non-life GWP ratio } & $71,80 \%$ & $67,88 \%$ & $63,99 \%$ & $64,04 \%$ & $63,23 \%$ & $59,70 \%$ & $56,86 \%$ & $56,27 \%$ & $54,50 \%$ \\
\hline \multicolumn{2}{|c|}{$\square$ VIG's life GWP ratio } & $28,20 \%$ & $32,12 \%$ & $36,01 \%$ & $35,96 \%$ & $36,77 \%$ & $40,30 \%$ & $43,14 \%$ & $43,73 \%$ & $45,50 \%$ \\
\hline
\end{tabular}

Source: Author's own work based on insurers' annual reports 


\section{Structure of Insurance Portfolio of Non-life Insurance}

Insurers KOOP and ČPP dominate in non-life insurance and non-life insurance IP reached almost $70 \%$ of market share within overall GWP in 2013. Table 2 compares the development of IP of non-life insurance of KOOP, ČPP and VIG by GWP share. IP are selected by ČAP's categories. The insurance company PČS does not conclude these types of IP. GWP of non-life insurance of PČS is included in the overall calculation of VIG under the category of Other Insurance. It is namely accident insurance, illness insurance and insurance covering various financial losses. Table 2 also includes civil and business insurance. These IP are assembled after selecting relevant items and subsequent summation of GWP of property insurance and liability insurance.

Table 2 Product diversification of the insurance portfolio of non-life insurance within VIG (Czech Republic)

\begin{tabular}{|c|c|c|c|c|c|c|c|c|c|c|}
\hline IP & Insurer & 2005 & 2006 & 2007 & 2008 & 2009 & 2010 & 2011 & 2012 & 2013 \\
\hline \multirow{3}{*}{$\begin{array}{l}\text { Compulsory } \\
\text { insurance, } \\
\%\end{array}$} & KOOP & 18.05 & 18.90 & 19.80 & 20.86 & 20.76 & 21.37 & 22.94 & 23.66 & 23.85 \\
\hline & ČPP & 0 & 0 & 0 & 0 & 0 & 0 & 0 & 0 & 0 \\
\hline & VIG & 15.66 & 16.36 & 17.05 & 17.73 & 17.33 & 17.36 & 18.33 & 18.73 & 18.80 \\
\hline \multirow{3}{*}{$\begin{array}{l}\text { Property } \\
\text { insurance, } \\
\%\end{array}$} & KOOP & 25.19 & 24.73 & 22.83 & 22.28 & 23.07 & 23.88 & 23.73 & 24.57 & 25.21 \\
\hline & ČPP & 11.73 & 9.85 & 9.86 & 10.29 & 10.46 & 10.40 & 11.46 & 12.45 & 13.27 \\
\hline & VIG & 23.40 & 22.72 & 21.01 & 21.45 & 20.94 & 21.09 & 20.93 & 21.68 & 22.31 \\
\hline \multirow{3}{*}{$\begin{array}{l}\text { Liability } \\
\text { insurance, } \\
\%\end{array}$} & KOOP & 7.40 & 6.66 & 6.64 & 6.90 & 7.15 & 7.02 & 7.66 & 8.34 & 8.30 \\
\hline & ČPP & 4.18 & 5.18 & 4.32 & 4.89 & 4.71 & 4.79 & 5.24 & 5.68 & 6.20 \\
\hline & VIG & 6.97 & 6.46 & 6.31 & 6.58 & 6.73 & 6.49 & 7.02 & 7.62 & 7.68 \\
\hline \multirow{3}{*}{$\begin{array}{l}\text { Motor } \\
\text { vehicle } \\
\text { insurance, } \\
\% \\
\end{array}$} & KOOP & 18.22 & 19.24 & 20.63 & 20.49 & 19.88 & 19.03 & 18.22 & 17.52 & 17.47 \\
\hline & ČPP & 7.83 & 11.53 & 12.61 & 13.01 & 14.82 & 16.62 & 18.34 & 18.95 & 20.10 \\
\hline & VIG & 16.54 & 18.19 & 19.49 & 19.32 & 18.98 & 18.14 & 17.71 & 17.26 & 17.46 \\
\hline \multirow{3}{*}{$\begin{array}{l}\text { Motor } \\
\text { vehic. } \\
\text { liability } \\
\text { insur., \% } \\
\end{array}$} & KOOP & 26.68 & 25.85 & 24.62 & 23.85 & 23.32 & 22.80 & 20.97 & 19.82 & 19.38 \\
\hline & ČPP & 73.52 & 68.60 & 67.97 & 65.99 & 64.23 & 61.19 & 56.73 & 52.07 & 50.25 \\
\hline & VIG & 32.86 & 31.53 & 30.52 & 29.96 & 29.84 & 28.50 & 26.51 & 25.00 & 24.52 \\
\hline \multirow{4}{*}{$\begin{array}{l}\text { Other } \\
\text { insurance, } \\
\%\end{array}$} & KOOP & 4.45 & 4.62 & 5.48 & 5.63 & 5.82 & 5.90 & 6.49 & 6.08 & 5.79 \\
\hline & ČPP & 2.74 & 4.84 & 5.24 & 5.82 & 5.79 & 6.99 & 8.24 & 10.84 & 10.18 \\
\hline & PČs & 100.00 & 100.00 & 100.00 & 100.00 & 100.00 & 100.00 & 100.00 & 100.00 & 100.00 \\
\hline & VIG & 4.27 & 4.74 & 5.64 & 5.96 & 6.18 & 8.39 & 9.50 & 9.71 & 9.23 \\
\hline \multirow{3}{*}{$\begin{array}{l}\text { Civil } \\
\text { insurance, } \\
\%\end{array}$} & KOOP & 6.78 & 7.17 & 7.61 & 7.78 & 8.30 & 9.15 & 9.67 & 9.99 & 10.22 \\
\hline & ČPP & 0.83 & 1.05 & 1.47 & 2.49 & 2.55 & 2.60 & 2.86 & 3.11 & 3.33 \\
\hline & VIG & 5.99 & 6.34 & 6.75 & 6.98 & 7.34 & 7.86 & 8.22 & 8.46 & 8.67 \\
\hline \multirow{3}{*}{$\begin{array}{l}\text { Business } \\
\text { insurance, } \\
\%\end{array}$} & KOOP & 24.61 & 22.86 & 20.55 & 20.21 & 20.56 & 21.66 & 20.39 & 21.35 & 21.56 \\
\hline & ČPP & 13.28 & 13.32 & 8.39 & 7.80 & 7.90 & 7.80 & 8.59 & 9.34 & 9.95 \\
\hline & VIG & 23.10 & 21.56 & 18.84 & 18.33 & 18.44 & 18.87 & 17.77 & 18.57 & 18.82 \\
\hline
\end{tabular}

Source: Author's own work based on ČAP's statistics

$10 \%$ of the total GWP were achieved by four KOOP's IP throughout the period. Another important IP is the business insurance. In 2013, property insurance reached the highest percentage (25.21\%). In 2013, civil insurance exceeded the $10 \%$ threshold for the first time. The most significant change occurred in liability insurance 
of motor vehicles. It dropped from $27 \%$ to $19 \%$. All products, except for liability insurance and civil insurance, reached average levels of around $20 \%$. Distribution of IP within the insurance portfolio can be evaluated as even.

ČPP achieved a $10 \%$ market share with its three IP. Business insurance cannot be included here because there was a decline, and except for 2005 and 2006 it did not even reach $10 \%$. In 2013 liability insurance of motor vehicles reached the highest percentage $(50.25 \%)$ and extended the average value of $62 \%$ in the period; it decreased from $73.52 \%$ to $50.25 \%$. Within the portfolio we can observe the growth of motor vehicle insurance, from $7.83 \%$ to $20.10 \%$.

Within VIG, five insurance products reached $10 \%$ of GWP. Only liability insurance and civil insurance did not reach $10 \%$, however, these figures are growing. The highest average share for the period 2008-2013 was reached by liability insurance of motor vehicles with the amount of about $27 \%$. Other IP reached the average ratio of around $20 \%$. In all monitored IP it is possible to observe some growth, except for motor vehicle insurance and liability insurance of motor vehicles.

\subsection{Expense-to-revenue Ratio of Non-life Insurance Portfolio}

The first monitored indicator is the cost indicator loss ratio (LR). The lower values, the better for insurance companies. Figure 5 shows the development of this indicator. Given that the insurance company PČs has a very low share of non-life insurance, its evaluation will be considered marginal. However, the figures indicate a significant decline in this indicator and value in 2013 is the lowest of all within all monitored subjects.

Figure 5 Development of loss ratio within VIG (Czech Republic)

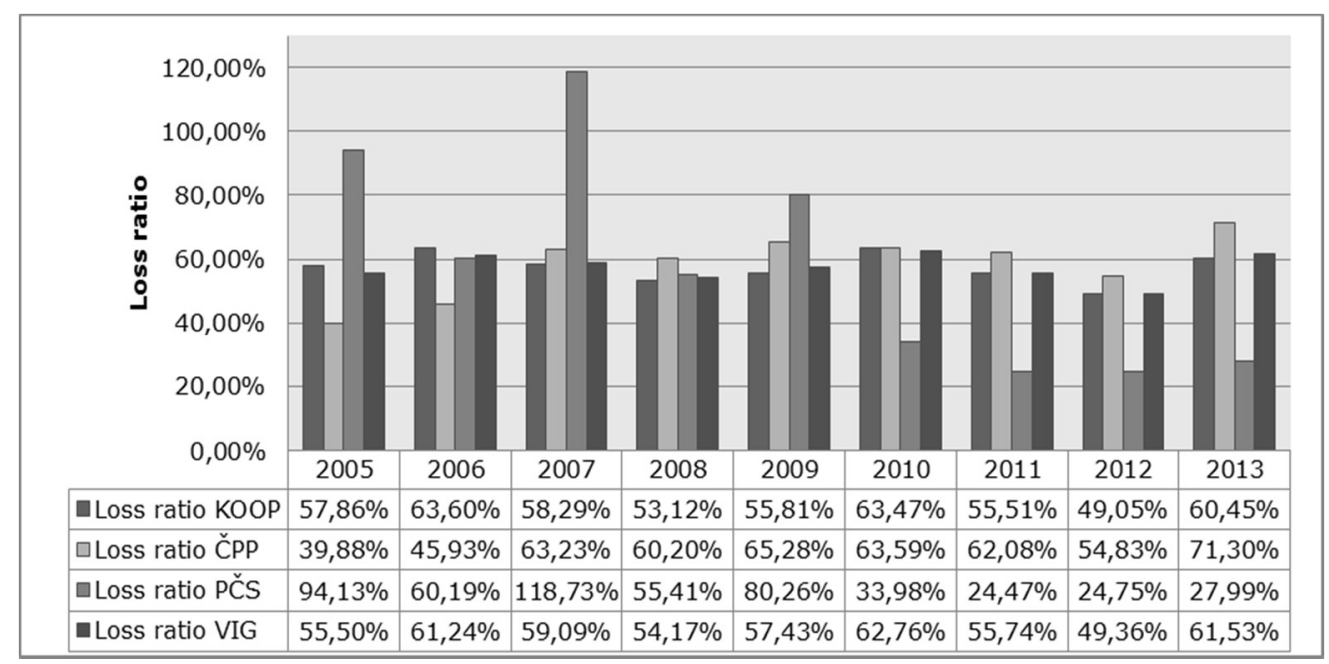

Source: Author's own work based on insurers' annual reports 
KOOP reached values up to $60 \%$, except for the years 2006 and 2013; all values fluctuated evenly in the period. ČPP reached higher values and a chronological development of the increase in this indicator can be observed. The value of $60 \%$ was exceeded within six years and in 2013 exceeded 70\%. The insurance group VIG slightly fluctuated between $54 \%$ and $63 \%$. It reached values below $60 \%$ in all monitored years except for 2006, 2010 and 2013.

The second monitored indicator is the ratio indicator expense ratio (ER). Insurance companies should not exceed $30 \%$. Figure 6 indicates the development of this indicator. Given that the insurance company PČs has a very low share of non-life insurance, its development will also be considered marginal. It is worth noting that the indicator value in the period 2010-2013 remained at a very low level.

KOOP shows even values in this indicator, reaching around $21 \%$. ČPP exceeded the value of $30 \%$ in 2007 and since this year, it has been fluctuating around this figure. Between 2010 and 2011, it got slightly below 30\% and in 2012 and 2013 again exceeded $30 \%$. Also VIG shows even values in this indicator, reaching around $22 \%$.

Figure 6 Development of expense ratio within VIG

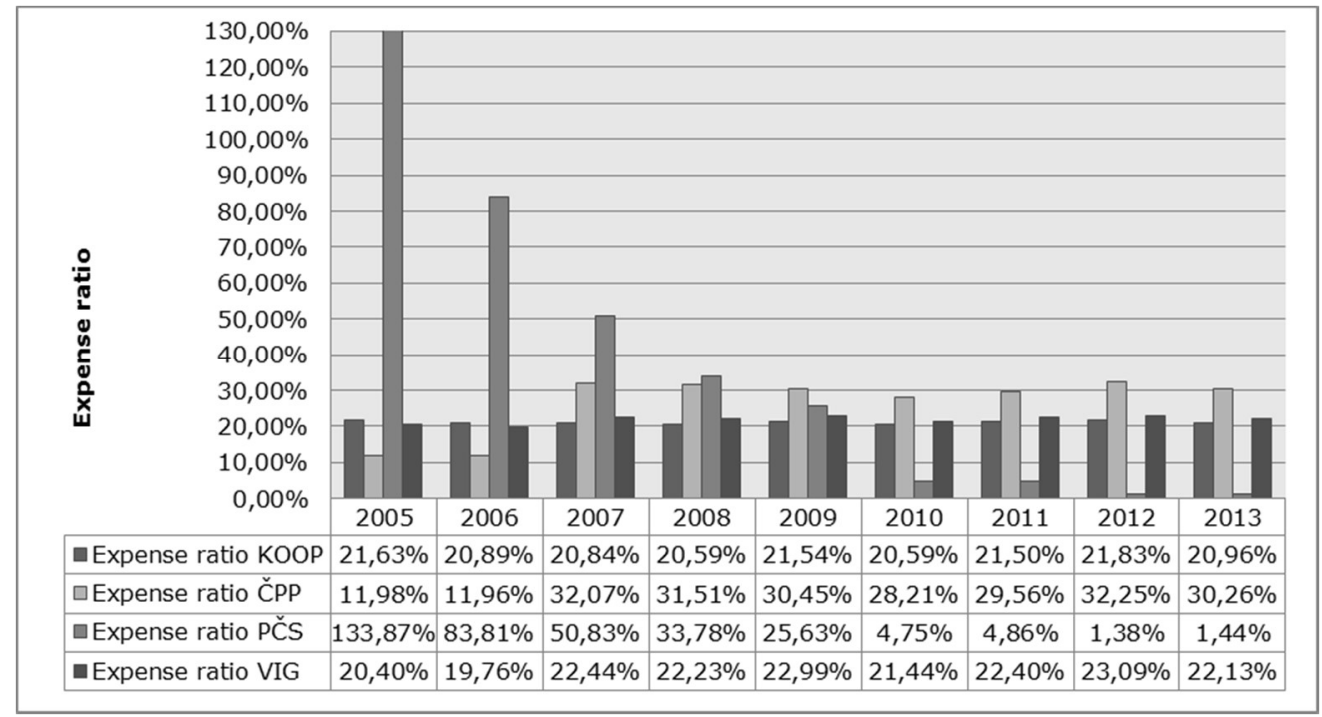

Source: Author's own work based on insurers' annual reports

\subsection{Comparison of the Insurance Business of the VIG}

Table 3 shows a comparison of selected indicators evaluating insurance activity by individual insurers and VIG. The indicators are briefly commented on. I listed values reached in 2013 and the average for the period 2005-2013 for insurance companies and for VIG for the period 2008-2013. 
Table 2 Comparison of VIG's insurance business (Czech Republic)

\begin{tabular}{|c|c|c|c|c|c|c|}
\hline \multirow[b]{2}{*}{ Indicator } & \multicolumn{3}{|c|}{ KOOP } & \multicolumn{3}{|c|}{ ČPP } \\
\hline & Evaluation & $\begin{array}{c}\text { Value in } \\
2013 \\
\end{array}$ & Average & Evaluation & $\begin{array}{c}\text { Value in } \\
2013 \\
\end{array}$ & Average \\
\hline $\begin{array}{l}\text { Market } \\
\text { share }\end{array}$ & $\begin{array}{l}2^{\text {nd }} \text { place for } \\
\text { the entire } \\
\text { period }\end{array}$ & $20.00 \%$ & $21.10 \%$ & $\begin{array}{c}7^{\text {th }} \text { place } \\
(2011-13 \\
2005)\end{array}$ & $4.62 \%$ & $4.00 \%$ \\
\hline $\begin{array}{l}\text { Relative } \\
\text { market share }\end{array}$ & $\begin{array}{l}\text { High level }(>3) \\
\text { for the entire } \\
\text { period }\end{array}$ & 10.40 & 10.86 & $\begin{array}{l}\text { Good level } \\
(1.5-3) \text { for } \\
\text { the entire } \\
\text { period }\end{array}$ & 2.40 & 2.07 \\
\hline $\begin{array}{l}\text { Growth of } \\
\text { GWP }\end{array}$ & $\begin{array}{l}\text { Slightly } \\
\text { unsteady } \\
\text { character }\end{array}$ & $\begin{array}{c}2.30 \% \\
(2012 / 13)\end{array}$ & $2.13 \%$ & $\begin{array}{l}\text { High growth } \\
(2006-10)\end{array}$ & $3.84 \%$ & $8.04 \%$ \\
\hline $\begin{array}{l}\text { Non-life } \\
\text { insurance } \\
\text { share }\end{array}$ & $\begin{array}{l}\text { Except for } \\
2013, \text { it } \\
\text { exceeds } 70 \% \text {. } \\
\text { Non-life share } \\
\text { being reduced. }\end{array}$ & $68.44 \%$ & $73.85 \%$ & $\begin{array}{c}\text { Except } 2012 \\
\text { a } 2013 \\
\text { exceeding } \\
70 \% \text {, non- } \\
\text { life share } \\
\text { being } \\
\text { reduced } \\
\end{array}$ & $69.18 \%$ & $73.30 \%$ \\
\hline $\begin{array}{l}\text { Product } \\
\text { diversification }\end{array}$ & $\begin{array}{c}\text { Equal } \\
\text { distribution }\end{array}$ & $\begin{array}{c}5 \text { IP } \\
\text { exceed } \\
10 \%\end{array}$ & $\begin{array}{c}5 \text { IP- } 20 \% \\
2 \text { IP- } 8 \%\end{array}$ & $\begin{array}{l}\text { Uneven } \\
\text { distribution. } \\
\text { Specializing } \\
\text { in car } \\
\text { insurance }\end{array}$ & $\begin{array}{l}3 \text { IP } \\
\text { exceed } \\
10 \%\end{array}$ & $\begin{array}{c}\text { Mot. } \\
\text { vehicles } \\
\text { liab. ins.: } \\
62 \% \\
2 \mathrm{IP}- \\
10 \% \\
\end{array}$ \\
\hline Loss ratio & $\begin{array}{c}53 \%-64 \% \\
60 \% \text { exceeded } \\
\text { in } 2 \text { years, } \\
\text { slight } \\
\text { fluctuation }\end{array}$ & $60.45 \%$ & $57.46 \%$ & $\begin{array}{c}39 \%-72 \%, \\
60 \% \\
\text { exceeded } \\
\text { in } 6 \text { years, } \\
\text { indicator } \\
\text { growing }\end{array}$ & $71.30 \%$ & $58.48 \%$ \\
\hline Expense ratio & $\begin{array}{c}20 \%-22 \% \\
\text { never } \\
\text { exceeded } 30 \%\end{array}$ & $20.96 \%$ & $21.15 \%$ & $\begin{array}{c}11 \%-33 \% \\
30 \% \\
\text { exceeded in } \\
5 \text { years }\end{array}$ & $30.26 \%$ & $26.47 \%$ \\
\hline \multirow[b]{2}{*}{ Indicator } & \multicolumn{3}{|c|}{ PČs } & \multicolumn{3}{|c|}{ VIG } \\
\hline & Evaluation & $\begin{array}{l}\text { Value in } \\
2013\end{array}$ & Average & Evaluation & $\begin{array}{c}\text { Value in } \\
2013\end{array}$ & Average \\
\hline $\begin{array}{l}\text { Market } \\
\text { share }\end{array}$ & $\begin{array}{c}5^{\text {th }} \text { place } \\
(2011-13) \\
10^{\text {th }} \text { place } \\
(2005)\end{array}$ & $7.25 \%$ & $5.24 \%$ & $\begin{array}{l}\text { 2th place } \\
\text { within } \\
\text { insurance } \\
\text { groups }\end{array}$ & $31.87 \%$ & $30.87 \%$ \\
\hline $\begin{array}{l}\text { Relative } \\
\text { market share }\end{array}$ & $\begin{array}{l}\text { High level }(>3) \\
\text { for the period } \\
2010-13\end{array}$ & 3.77 & 2.74 & $\begin{array}{l}\text { High level } \\
(>3) \text { for the } \\
\text { entire period }\end{array}$ & 16.57 & 16.36 \\
\hline GWP & $\begin{array}{c}\text { Highly } \\
\text { fluctuating, } \\
\text { high growth }\end{array}$ & $6.11 \%$ & $23.59 \%$ & $\begin{array}{l}\text { Slightly } \\
\text { fluctuating }\end{array}$ & $3.36 \%$ & $3.11 \%$ \\
\hline $\begin{array}{l}\text { Non-life } \\
\text { insurance } \\
\text { share }\end{array}$ & $\begin{array}{l}\text { Specializing in } \\
\text { life insurance, } \\
\text { bancassurance, } \\
\text { growth of non- } \\
\text { life share }\end{array}$ & $6.70 \%$ & $3.74 \%$ & $\begin{array}{c}\text { Positive } \\
\text { development, } \\
\text { non-life } \\
\text { insurance } \\
\text { share } \\
\text { decreasing } \\
\end{array}$ & $54.5 \%$ & $59.10 \%$ \\
\hline $\begin{array}{l}\text { Product } \\
\text { diversification }\end{array}$ & $\begin{array}{l}\text { Focus on life } \\
\text { insurance and } \\
\text { bancassurance }\end{array}$ & $\begin{array}{c}\text { Not } \\
\text { evaluated }\end{array}$ & $\begin{array}{c}\text { Not } \\
\text { evaluated }\end{array}$ & $\begin{array}{c}\text { Even } \\
\text { distribution }\end{array}$ & $\begin{array}{c}5 \text { IP } \\
\text { exceeded } \\
10 \%\end{array}$ & $\begin{array}{c}\text { Mot. } \\
\text { vehic. } \\
\text { liab. ins. - } \\
27 \% \\
4 \mathrm{IP}- \\
20 \%, \\
2 \mathrm{IP}-8 \%\end{array}$ \\
\hline Loss ratio & $\begin{array}{c}2010-2013 \\
\text { significant drop } \\
\text { under } 5 \%\end{array}$ & $\begin{array}{l}27.99 \%, \\
\text { low share } \\
\text { of non-life }\end{array}$ & $\begin{array}{l}57.77 \%, \\
\text { low level } \\
\text { of non-life }\end{array}$ & $\begin{array}{c}\text { Slight } \\
\text { fluctuation, } \\
\text { values under }\end{array}$ & $61.53 \%$ & $56.83 \%$ \\
\hline
\end{tabular}




\begin{tabular}{|c|c|c|c|c|c|c|}
\hline & & insurance & insurance & $\begin{array}{c}60 \% \text { except } \\
2013\end{array}$ & & \\
\hline Expense ratio & $\begin{array}{c}2010-2013 \\
\text { significant drop } \\
\text { under } 5 \%\end{array}$ & $\begin{array}{c}1.44 \%, \\
\text { low share } \\
\text { of non-life } \\
\text { insurance }\end{array}$ & $\begin{array}{l}37.82 \% \text {, } \\
\text { low level } \\
\text { of non-life } \\
\text { insurance }\end{array}$ & $\begin{array}{c}20 \%-23 \% \\
30 \% \text { not } \\
\text { exceeded }\end{array}$ & $22.13 \%$ & $22.38 \%$ \\
\hline
\end{tabular}

Source: Author's own work

\section{Conclusions}

This article aims to determine whether the developments in the insurance business production correspond with the development of the expense-to-revenue ratio of insurance portfolios. KOOP, ČPP, PČS and the insurance group VIG are evaluated by position in the insurance market, according to operating costs and insurance benefits costs for the period 2005-2013.

Because PČs is an insurance company specializing in life insurance, only insurance companies KOOP and ČPP are evaluated complexly. There are differences between KOOP and ČPP. The development of KOOP is a development of a stable insurance company in all indicators. ČPP is proved to be an insurance company with significant growth in the Czech market share. But the results in product diversification have shown an uneven distribution. Cost ratios have indicated increase in the monitored period. KOOP, having ranked second in the Czech insurance market, can be evaluated, in terms of its market position, as stable. KOOP's indicators of market share, relative share and growth of GWP are slightly fluctuating. Product diversification is even. This insurer is a universal insurance company with a predominance of non-life insurance ( $70 \%$ share). Loss ratio is in the range between $53 \%$ and $60 \%$, expense ratio is in the range between $20 \%$ and $22 \%$. Expense ratios also show a slightly fluctuating development. We can say that the development of the KOOP's commercial production corresponds with developments in the cost of the insurance portfolio.

ČPP insurance company has ranked $7^{\text {th }}$ (2013) in the Czech insurance market. It is a universal insurance company which specializes in insurance of motor vehicles and motor vehicles liability insurance. In terms of market position, it can be evaluated as an insurance company with significant growth in market share and relative share. In the monitored period it is also evident that its GWP grew significantly. Product diversification is uneven. This is caused by the increased share of motor vehicles liability insurance and motor vehicle insurance. In terms of temporal evolution we can positively assess ČPP's reducing GWP proportion for these insurance products. Loss ratio is in the range between $39 \%$ and $72 \%$ and expense ratio in the range between $11 \%$ and $33 \%$. Cost ratios show a slight increase. We can say that ČPP's development of commercial production does not correspond with the development of cost of the insurance portfolio. In the monitored period, both cost ratios rose. The insurance company should focus on product diversification of its insurance portfolio and its expense-to-revenue ratio strategy for its insurance portfolio. 
PČs has ranked $5^{\text {th }}$ (2013) in the Czech insurance market. It is an insurance company specializing in life insurance in form of bancassurance. For this reason, this insurer has not been evaluated within production diversification and expense-torevenue ratio. In terms of market position, it can be evaluated as an insurance company with significant market growth and relative share.

VIG's overall results are, due to the structure of individual insurance companies, very positive, both in terms of market position, and in terms of expense-to-revenue ratio. These results would not have been reached without the high market share of KOOP and growth of PČs, which focuses on the life segment.

\section{References}

ČAP (2015). Individuální výsledky členů. Retrieved from: http://www.cap.cz/statisticke-udaje/individualni-vysledky-clenu.

Česká podnikatelská pojištóvna, a. s., Vienna Insurance Group (2015). Výroční zprávy 2005-2013. Retrieved from: http://www.cpp.cz/profil/https://www. pojistovnacs.cz/o-nas/vyrocni-zpravy/.

ČNB (2015). Základní ukazatele o sektorech finančního trhu. Retrieved from: http://www.cnb.cz/cs/dohled_financni_trh/souhrnne_informace_fin_trhy/zakladni_uk azatele_fin_trhu/.

ČNB (2015). Zpráva o výkonu dohledu za rok 2007. Retrieved from: http://www.cnb.cz/miranda2/export/sites/www.cnb.cz/cs/dohled_financni_trh/souhrn ne_informace_fin_trhy/zpravy_o_vykonu_dohledu/download/dnft_2007_cz.pdf.

Gestel, T., Martens, D., Baesens, B., Feremans, D., Huysmans, J., Vanthienen, J. (2007). Forecasting and analyzing insurance companies' ratings. International Journal of Forecasting, 23(3), pp. 513-529. DOI: 10.1016/j.ijforecast.2007. 05.001 .

Kooperativa pojištóvna, a.s., Vienna Insurance Group (2015). Výroční zprávy 20052013. Retrieved from: http://www.koop.cz/o-nas/zakladni-informace/vyrocnizpravy/.

Korobczuk, L. (2007). Informační výstupy pojištoven. Analýza výroční zprávy. Presentation within tutoring of a publication Čejková, V. and Valouch, P. (2005). Účetnictví pojištoven po vstupu do EU. Praha: Grada.

Lhotská, K. (2012). Pohledem analytika: Co ohrožuje pojistný trh? Pojistný obzor, 89(2), pp. 23-24.

Lhotská, K. (2013). Pojistný kmen-„Rodinné stříbro" bez lesku. Pojistný obzor, 90(3), pp. 28-29.

Lhotská, K. (2015). 2015 - Čeká nás stagnace?. Pojistný obzor, 92(1), pp. 11-13.

Moody's (2012). Retrieved from: https://www.moodys.com/research/GlobalProperty-and-Casualty-Insurers--PBC_161516.

Pojištovna České spořitelny, a. s., Vienna Insurance Group (2015). Výroční zprávy 2005-2013. Retrieved from: https://www.pojistovnacs.cz/o-nas/vyrocni-zpravy/. 
Pulchart, V. (2002). K ziskovosti neživotního pojištění - pohled na dlouhodobé trendy ve světě. Pojistný obzor, 79(10), pp. 4-5.

Vávrová, E. (2014). Finanční rízení komerčních pojištoven. Praha: Grada.

Řezáč, F. et al. (2009). Marketingové řízení komerční pojištóvny. Brno: Masarykova universita. 